\title{
Hubungan Kualitas Kerohanian, Struktur Pelayanan dan Ibadah yang Membangkitkan Inspirasi Terhadap Pertumbuhan Gereja di GBI House of Glory Batam
}

\author{
Fredy Simanjuntak ${ }^{1 *}$, Johannes Tarigan ${ }^{2}$, Jan Lukas Lombok ${ }^{3}$ \\ ${ }^{1,2,3}$ Prodi Teologi, STT Real Batam \\ fredygrace@gmail.com
}

\begin{abstract}
This paper is an analysis of church growth based on the principle of natural church growth. As an organism as well as an organization, it is natural and natural for the church to experience healthy and maximum growth. To measure church growth at GBI House of Glory Batam, researchers used three of the eight quality characteristics of a healthy church as described by Christian A. Schwarz (1996). Some of these characteristics include (1) Thirsty and Enthusiastic Spirituality, (2) Appropriate Service Structures, (3) Inspirational Worship. The purpose of this study is to analyze the Church's services at GBI House of Glory Batam in relation to the application of Biblical principles in order to produce a growing Church. The method used in this research is the descriptive quantitative method. Simultaneous results of the three variables above show a coefficient value of 0.622 on church growth.

Keywords: Spiritual Quality, Service Structure, Inspiring Worship, Church GrowthGBI House of Glory Batam
\end{abstract}

\begin{abstract}
Abstrak
Makalah ini merupakan analisis pertumbuhan gereja berdasarkan prinsip pertumbuhan gereja secara alami. Sebagai organisme sekaligus organisasi, wajar dan wajar jika gereja mengalami pertumbuhan yang sehat dan maksimal. Untuk mengukur pertumbuhan gereja di GBI House of Glory Batam, peneliti menggunakan tiga dari delapan karakteristik kualitas gereja yang sehat seperti yang dijelaskan oleh Christian A. Schwarz (1996). Beberapa ciri tersebut antara lain: (1) Spiritualitas Haus dan Antusias, (2) Struktur Pelayanan yang Tepat, (3) Ibadah yang Inspiratif. Tujuan penelitian ini adalah untuk menganalisis pelayanan Gereja di GBI House of Glory Batam dalam kaitannya dengan penerapan Prinsip-Prinsip Alkitab dalam rangka menghasilkan Gereja yang bertumbuh. Metode yang digunakan dalam penelitian ini adalah metode deskriptif kuantitatif.

Kata kunci: Kualitas Rohani, Struktur Pelayanan, Ibadah yang Menginspirasi, Pertumbuhan Gereja, GBI House of Glory Batam
\end{abstract}




\section{PENDAHULUAN}

Pertumbuhan gereja adalah tentang pelayanan, bukan materialisme. Oleh karena itu motif akan pertumbuhan gereja tidak dapat salah arah dan tidak realistis (Galatia 5:13). Tuhan akan memakai gereja yang melayani dengan baik untuk melayani lebih banyak anggota. Sangat menarik untuk menyaksikan dan berpartisipasi dalam pertumbuhan yang sehat ketika tangan Tuhan yang sempurna ada di dalamnya. Tetapi ketika pertumbuhan merupakan semata-mata buatan manusia, gereja mungkin terjebak dalam pasir apung. Seperti pasir hisap yang tanpa disadari membahayakan secara perlahan, dan semakin berjuang untuk keluar, semakin dalam tenggelam. Namun di sisi lain pertumbuhan gereja tidak dapat dipandang sebagai sesuatu yang otomatis - diberikan dan oleh karena itu diterima begitu saja.

Pertumbuhan gereja yang seimbang adalah pertumbuhan gereja yang sehat. Demikian dalam pertumbuhannya Gereja tidak terlepas dari kepemimpinanyang sehat pula. Itu membutuhkan pemimpin gereja yang menjalani kehidupan rohani yang seimbang dan sehat. Tidak ada gereja yang dapat atau akan tumbuh melampaui tingkat spiritual para pemimpinnya. Teknik dan strategi pertumbuhan gereja bukanlah pengganti bagi para pemimpin seperti Kristus yang memiliki panggilan Tuhan dan rasa prioritas. Pertumbuhan gereja pada akhirnya bergantung pada Yesus Kristus, karena itu adalah gereja-Nya. Semakin baik kita mengikuti pimpinan-Nya, semakin baik gereja-gereja lokal bertumbuh dan makmur. ... Kita harus bertumbuh dalam semua aspek Dia, yang adalah Kepala, bahkan Kristus. (Efesus 4:15).

Menurut Elmer Town ukuran bertumbuhnya suatu gereja tidak hanya didasarkan pada kuantitas pengunjung kebaktian atau jumlah jemaat yang dibaptis. Ia juga menyebutkan aspek lain seperti, pertumbuhan internal (kerohanian), pertumbuhan ekspansi (penanaman Gereja baru), pertumbuhan eksternal (jumlah kehadiran secara numerik), pertumbuhan biologis (berdasarkan kelahiran dari anggota jemaat), pertumbuhan pertobatan (usaha penginjlan atau penjangkauan bagi orang yang belum mengenal Kristus), pertumbuhan perpindahan (perpindahan keanggotaan), pertumbuhan ekstensi (pelayanan penajngkauan kepada suatu etnis). ${ }^{1}$

Jadi dapat disimpulkan seperti yang di paparkan oleh Yakob Tomatala, bahwa gereja yang bertumbuh adalah gereja yang sehat. Gereja yang sehat dan bertumbuh memiliki ciri dan tanda yang khusus. ${ }^{2}$ Lebih jauh

\footnotetext{
${ }^{1}$ Elmer Towns, Effective Evangelism View: Church Growth Effectively Confronts and Penetrate Culture," Dalam Evaluating Church Growth Movement: 5 Views, Ed. Gary McIntosh (Grand Rapids: Zondervan, 2004).44-45

${ }^{2}$ Yakob Tomatala, Teologi Misi (Jakarta: YT Leadership Foundation, 2003).220
} 
lagi Yakob Tomatala mengutip C. Peter Wagner, gereja yang sehat dan bertumbuh memiliki keseimbangan hubungan dinamis pola hidup, dan ibadah jemaat. ${ }^{3}$ Gereja yang bertumbuh adalah gereja yang mengalami pertumbuhan atau peningkatan, baik secara kualitas ataupun secara kuantitas. ${ }^{4}$ Secara kualitas, pertumbuhan gereja dapat dilihat dari peningkatan kerohanian anggota jemaat gereja. Sedangkan secara kuantitas, pertumbuhan gereja dapat dilihat dari pertambahan jumlah keanggotaan gereja. Gereja yang sehat itu diawali dari pertumbuhan secara kualitas yang menuju kepada pertumbuhan secara kuantitas. ${ }^{5}$

Dalam paper ini penulis mencoba mengaitkan hal pertumbuhan gereja melalui pendekatan berdasarkan prinsip pertumbuhan gereja alamiah yang dikembangkan oleh Christian A. Schwarz. Schwarz menyadari bahwa begitu banyak model pertumbuhan gereja yang mendorong gereja menirunya. Banyak dari model-model itu disebut "mega-churches" yang memiliki sukses yang sangat terkenal dlam pertumbuhan gereja. Schwarz menyadari juga bahwa sekalipun kita dapat mempelajarinya, kesemuanya itu seringkali tidak bisa cocok untuk semua gereja. Proyek risetnya berfokus pada prinsip-prinsip yang memang ada dalam gereja-gereja yang sukses, yang dianalisanya berdasarkan pola pertumbuhan kualitas dan angka. Dalam tulisannya Schwarz mengidentifikasi 8 karakteristik kualitas yang jika kesemuanya ada dalam sebuah gereja secara cukup maka secara praktis akan menjamin pertumbuhan angka. Karakteristik ini adalah sebagai berikut: ${ }^{6}$

1. Kepemimpinan yang melakukan pemberdayaan

2. Pelayanan yang berorientasi pada karunia

3. Kerohanian yang haus dan penuh antusiasme

4. Struktur pelayanan yang tepat guna

5. Ibadah yang membangkitkan inspirasi

6. Kelompok kecil yang menjawab kebutuhan secara menyeluruh

7. Penginjilan yang berorientasi pada kebutuhan

8. Hubungan yang penuh kasih

Penulis akan menggunakan 3 indicator dari 8 karakteristik dalam mengukur pertumbuhan gereja GBI House of Glory Windsore Batam Dengan pemahaman dan penerapan prinsip-prinsip pertumbuhan gereja alamiah

\footnotetext{
${ }^{3}$ Ibid.

${ }^{4}$ Peter Wongso, Tugas Gereja Dan Misi Masa Kini (Surabaya: Yakin, 1981).80

${ }^{5}$ Kejar Hidup Laia, "Pertumbuhan Gereja Dan Penginjilan Di Kepulauan Nias," Jurnal Fidei 2, no. 2 (2019): 286-302.

${ }^{6}$ Christian A. Schwarz, Pertumbuhan Gereja Yang Alamiah, Terj. Budijanto (Jakarta: Metanoia, 1996).22-37
} 
diharapkan bahwa GBI House of Glory akan menjadi gereja yang sehat sehingga dapat bertumbuh secara wajar dan normal.

Sebagaimana telah diuraikan pada latar belakang penulisan karya ilmiah, maka kajian masalah yang akan diteliti adalah:

Pertama, bagaimana kualitas Kerohanian, Struktur Pelayanan dan Ibadah yang ada di jemaat GBI House of Glory Batam, kedua, bagaimana keadaan pertumbuhan jemaat GBI House of Glory Batam, ketiga, sejauh mana hubungan Kualitas Kerohanian, Struktur Pelayanan dan Ibadah dapat meningkatkan Pertumbuhan jemaat GBI House of Glory Batam.

\section{METODE}

Penelitian ini bersifat kuantitatif dimana data yang dihasilkan akan berbentuk angka. Dari data yang didapat dilakukan analisis dengan menggunakan software SPSS 22. Penelitian ini memiliki tujuan untuk menganalisis hubungan, Kualitas Kerohanian, Struktur Pelayanan dan Ibadah Terhadap Pertumbuhan Gereja di GBI House of Glory Batam, data dikumpulkan dengan kuesioner sebanyak 47 responden yang berjemaat di GBI House of Glory Batam yang sasarannya para pelayan jemaat/aktivis yang aktif dalam perbagai kegiatan dan agenda gereja. Penyebaran kuesioner dilakukan secara tertutup dengan menggunakan skala likert $1-5$. Penelitian ini menggunakan 3 variabel independen yang terdiri kualitas kerohanian, struktur pelayanan, dan kualitas ibadah serta variabel dependen yaitu pertumbuhangereja. Kuesioner yang dibuat dengan variabel yang diteliti memiliki rata 4 item pertanyaan. Harapan penulis melalui penelitian ini seperti yang dituliskan oleh Dwijo Saputro memotivasi gereja yang sungguh sungguh untuk menuai jiwa-jiwa bagi perluasan KerajaanNya. ${ }^{7}$

\section{Karakteristik Responden}

Karakteristik responden merupakan ragam latar belakang yang dimiliki responden itu sendiri. Karakteristik ini untuk melihat responden memiliki background seperti apa yang dalam penelitian ini background responden difokuskan pada jenis kelamin, umur, lamanya berjemaat jabatan dalam pelayanan dan tingkat frekuensi. Hasil yang didapat adalah:

Berdasarkan Tabel 4.1 diatas penelitian ini menggunakan responden sebanyak 47 sampel pelayan jemaat dimana dari sampel yang dipilih apabila dilihat dari segi jenis kelamin secara keseluruhan sampel berjenis kelamin perempuan

\footnotetext{
${ }^{7}$ Dwidjo Saputro, "Injil Dalam Ruang Kekuatan Keluarga Dan Pernikahan," Webinar Great Commission As Family Lasting Legacy, STT REAL BATAM.
} 
sebanyak $63.8 \%$ dan sisanya laki-laki sebanyak 36.2\%. Ini menunjukkan dikalangan jemaat keputusan mayoritas pelayan aktif lebih banyak dilakukan perempuan. Dengan rentang lamanya berjemaat $<1$ Tahun $12.8 \%,>1-4$ Tahun sama dengan $44.7 \%$, dan $>5$ Tahun sama dengan $42.6 \%$. Sementara untuk tingkat usia 20-30 Tahun 70.2\%, 31-40 sebanyak 21\%, 41-50 sebesar $8.5 \%$.

Penyajian data merupakan deskripsi atau gambaran data dari masingmasing variabel yang diperoleh dari hasil penelitian di lapangan. Variabel dalam penelitian ini antara lain variabel Kualitas kerohanian (X1), Struktur Pelayanan yang tepat Guna (X2) dan Kualitas Ibadah (X3). Paparan data ini untuk menguraikan kecenderungan jawaban responden dari tiap-tiap variabel, sehingga nantinya dapat diketahui seberapa besar tingkat keberhasilan penelitian yang dilakukan. Data dalam penelitian ini akan dideskripsikan ke dalam tabel distribusi frekuensi atau dikelompokkan sesuai dengan masing-masing variabel, maka data penelitian secara deskriptif statistik adalah sebagai berikut:

\section{HASIL DAN PEMBAHASAN}

\section{Pendidikan Agama Kristen Bagi Remaja Madya Dimasa Pandemic Covid} 19

Fenomena Kualitas Kerohanian yang Haus dan Antusias

Data Kualitas Kerohanian yang Haus dan Antusias yang dikumpulkan dari responden sebanyak 47 secara kuantitatif menunjukkan bahwa skor minimum yang didapat adalah 13 dan skor total maksimumnya adalah 65 . Rentang jumlah skor maksimum yang mungkin diperoleh adalah $65-13=42$. Interval kelas sebanyak lima, maka lebar kelas intervalnya adalah $42: 5=10.4$.

Dari hasil angket, dapat dibuat distribusi frekuensi untuk variabel Kualitas kerohanian yang haus dan antusias (X1) sebagai berikut:

Tabel 1.1 Distribusi Frekuensi Kerohanian yang Haus dan Antusias

\begin{tabular}{|c|c|c|c|c|}
\hline $\mathrm{NNo}$ & Kriteria & Interval & Jumlah & Prosentase \% \\
\hline 1 & Sangat baik & $54.6-65$ & 20 & $42.55 \%$ \\
\hline 2 & Baik & $44.1-54.5$ & 24 & $51.06 \%$ \\
\hline 3. & Cukup Baik & $33.6-44$ & 3 & $6.38 \%$ \\
\hline 4 & Tidak Baik & $23.1-33.5$ & 0 & $0 \%$ \\
\hline 5 & Sangat tidak Baik & $13-23$ & 0 & $0 \%$ \\
\hline \multicolumn{3}{|c|}{ Total } & 47 & $100 \%$ \\
\hline
\end{tabular}


Berdasarkan data pada tabel 1.1 dan tabel 1.2 di atas menunjukkan bahwa tingkatan Kerohanian yang Haus dan Antusias dapat diperoleh 20 responden atau $42.55 \%$ memperoleh kriteria dengan sangat baik dan 51 responden atau 51.06\% responden memperoleh kriteria dengan baik. Dan 3 responden atau 6.38\% memperoleh kriteria cukup baik. Dengan demikian hasil penelitian ini menunjukkan bahwa sebagian besar responden dengan Kerohanian yang Haus dan Antusias Terhadap pertumbuhan Gereja GBI House of Glory Batam memperoleh kriteria baik.

\section{Struktur Pelayanan yang Tepat Guna}

Data Kualitas struktur pelayanan yang tepat guna yang dikumpulkan dari responden sebanyak 47 secara kuantitatif menunjukkan bahwa skor minimum yang didapat adalah 13 dan skor total maksimumnya adalah 45 . Rentang jumlah skor maksimum yang mungkin diperoleh adalah $45-9=36$. Interval kelas sebanyak lima, maka lebar kelas intervalnya adalah $36: 5=7.2$

Dari hasil angket, dapat dibuat distribusi frekuensi untuk struktur pelayanan yang tepat guna (X2) sebagai berikut:

Tabel 1.4 Distribusi Frekuensi struktur pelayanan yang tepat guna

\begin{tabular}{|c|c|c|c|c|}
\hline No & Kriteria & Interval & Jumlah & Prosentase \% \\
\hline 1 & Sangat baik & $37.8-45$ & 7 & $14 \%$ \\
\hline 2 & Baik & $30.5-37.7$ & 27 & $57.44 \%$ \\
\hline 3. & Cukup Baik & $23.2-30.4$ & 12 & $25.53 \%$ \\
\hline 4 & Tidak Baik & 15.9-23.1 & 1 & $2.12 \%$ \\
\hline 5 & Sangat tidak Baik & $9-15.8$ & 0 & $0 \%$ \\
\hline \multicolumn{3}{|c|}{ Total } & 47 & $100 \%$ \\
\hline
\end{tabular}

Berdasarkan data pada tabel 1.3 dan tabel 1.4 di atas menunjukkan bahwa tingkatan struktur pelayanan yang tepat guna dapat diperoleh 7 responden atau 14\% memperoleh kriteria dengan sangat baik dan 27 responden atau $57.44 \%$ responden memperoleh kriteria dengan baik, 12 responden atau $25.53 \%$ memperoleh kriteria cukup baik dan 1 responden memperoleh kriteria kurang baik 2,12\%. Dengan demikian hasil penelitian ini menunjukkan bahwa sebagian besar responden dengan struktur pelayanan yang tepat guna Terhadap pertumbuhan Gereja GBI House of Glory Batam memperoleh kriteria baik. 


\section{Ibadah yang Membangkitkan Inspirasi}

Data Kualitas Ibadah yang Membangkitkan Inspirasi yang dikumpulkan dari responden sebanyak 47 secara kuantitatif menunjukkan bahwa skor minimum yang didapat adalah 10 dan skor total maksimumnya adalah 50. Rentang jumlah skor maksimum yang mungkin diperoleh adalah $50-10=40$. Interval kelas sebanyak lima, maka lebar kelas intervalnya adalah $40: 5=8$.

Dari hasil angket, dapat dibuat distribusi frekuensi untuk variabel Ibadah yang Membangkitkan Inspirasi (X3) sebagai berikut:

Tabel 1.6 Distribusi Frekuensi Ibadah yang Membangkitkan Inspirasi

\begin{tabular}{|c|c|c|c|c|}
\hline NNo & Kriteria & Interval & Jumlah & Prosentase \% \\
\hline 1 & Sangat baik & $42-50$ & 19 & $40.42 \%$ \\
\hline 2 & Baik & $33-41$ & 21 & $44.68 \%$ \\
\hline 3. & Cukup Baik & $24-32$ & 7 & $14.89 \%$ \\
\hline 4 & Tidak Baik & $15-23$ & 0 & $0 \%$ \\
\hline 5 & Sangat tidak Baik & $10-14$ & 0 & $0 \%$ \\
\hline & \multicolumn{2}{|l|}{ Total } & 47 & $100 \%$ \\
\hline
\end{tabular}

Berdasarkan data pada tabel 1.5 dan tabel 1.6 di atas menunjukkan bahwa tingkatan Ibadah yang Membangkitkan Inspirasi dapat diperoleh 19 responden atau $40.42 \%$ memperoleh kriteria dengan sangat baik dan 21 responden atau $44.68 \%$ responden memperoleh kriteria dengan baik, 7 responden atau $14.89 \%$ memperoleh kriteria cukup baik. Dengan demikian hasil penelitian ini menunjukkan bahwa sebagian besar responden dengan Ibadah yang Membangkitkan Inspirasi Terhadap pertumbuhan Gereja GBI House of Glory Batam memperoleh kriteria baik.

\section{Hubungan Kualitas Kerohanian, Struktur Pelayanan dan Ibadah yang Membangkitkan Inspirasi Terhadap Pertumbuhan Gereja di GBI House of Glory Batam}

Kualitas kerohanian, struktur pelayanan dan ibadah yang membangkitkan Inspirasi adalah merupakan komponen penting yang berhubungan dengan pertumbuhan gereja.

Kualitas kerohanian terlihat dari kedewasaan rohani di dalam Kristus, menurut Himawan Djaya ada 3 ciri orang yang telah mengalami kedewasaan 
dalam Kristus: takut akan Tuhan, memanfaatkan potensi diri melalui pikiran, perkataan dan perbuatan, dan memiliki pola tingkah laku yang komprehensif. ${ }^{8}$

Penatalayanan gereja (jemaat) yang baik, tertib dan teratur harus menyangkut aspek: perencanaan, pengorganisasian, pelaksanaan, pengawasan, pelaporan dan pertanggung jawaban pelayanan. ${ }^{9}$ Seluruh penatalayanan dalam gereja mengenai sumber dayanya harus berkontribusi pada peneguhan dan penyatuan gereja, sebagai persiapan bagi pelayanan dan misi dunia. ${ }^{10}$

Ibadah yang membangkitkan inspirasi adalah ibadah yang di dalamnya ada hati yang mengasihi Kristus dan yang mengasihi orang-orang, jemaat yang menyanyi dengan sepenuh hati, keterbukaan terhadap pimpinan Roh Kudus, dan kerinduan untuk bersekutu dengan Allah Bapa. ${ }^{11}$

Hasil penelitian terakhir menunjukkan bahwa kualitas kerohanian, struktur pelayanan dan ibadah yang membangkitkan Inspirasi secara simultan berpengaruh positif terhadap pertumbuhan gereja dengan nilai koefisien sebesar 0,622, artinya kualitas kerohanian, struktur pelayanan dan ibadah yang membangkitkan Inspirasi berpengaruh kuat terhadap pertumbuhan gereja. Begitu pun dengan hasil perhitungan yang menunjukkan nilai sig. $(2$-tailed $)=$ 0,000 lebih kecil dari $=0,005$, yang dapat dimaknai tingkat signifikansi antara keduanya yang menunjukkan hubungan yang signifikan. Adapun koefisien determinasi (r2) yaitu sebesar $0,622=38.7 \%$, artinya pujian penyembahan berpengaruh sebesar $38.7 \%$ terhadap pertumbuhan gereja.

${ }^{8}$ Himawan Djaya Endra, Dewasa Dalam Kristus (Jakarta: CV Bina Media Informasi, 2003).21-32

${ }^{9}$ D.M.Lintong, Tugas Pelayanan Pendeta (Tomohon: Lembaga Telaah Agama dan Kebudayaan(LETAK), 2005).71-73

${ }^{10}$ Richard B. Cunningham, Creative Stewardship (Nashville: Abingdon Press, 1979).111-112

${ }^{11}$ Darrel W. Robinson, Total Church Life (Bandung: Lembaga Literatur Baptis, 1985). 64 
Tabel 1. Hubungan Kualitas Kerohanian, Struktur Pelayanan dan Ibadah yang Membangkitkan Inspirasi Terhadap Pertumbuhan Gereja

\begin{tabular}{|c|c|c|c|c|c|c|c|c|c|c|}
\hline \multicolumn{11}{|c|}{ Model Summaryb } \\
\hline \multirow[b]{2}{*}{ Model } & \multirow[b]{2}{*}{$\mathrm{R}$} & \multirow[b]{2}{*}{$\begin{array}{l}\text { R } \\
\text { Square }\end{array}$} & \multirow[b]{2}{*}{$\begin{array}{l}\text { Adjusted } \\
\text { R Square }\end{array}$} & \multirow[b]{2}{*}{$\begin{array}{l}\text { Std. Erro } \\
\text { of th } \\
\text { Estimate }\end{array}$} & \multicolumn{5}{|c|}{ Change Statistics } & \multirow[b]{2}{*}{$\begin{array}{l}\text { Furbin- } \\
\text { Watson }\end{array}$} \\
\hline & & & & & $\begin{array}{l}\text { R Square } \\
\text { Change }\end{array}$ & $\begin{array}{l}\text { F } \\
\text { Change }\end{array}$ & dfl & $\mathrm{df} 2$ & $\begin{array}{l}\text { Sig. } \\
\text { Change }\end{array}$ & \\
\hline & $.622^{\mathrm{a}}$ & .387 & .345 & 5.149 & 387 & 9.066 & 3 & 43 & .000 & 2.156 \\
\hline
\end{tabular}

a. Predictors: (Constant), Ibadah yang Membangkitkan Inspirasi, Struktur Pelayanan, Kualitas Kerohanian

b. Dependent Variable: Pertumbuhan Gereja

\section{KESIMPULAN}

Kualitas kerohanian, struktur pelayanan dan ibadah yang membangkitkan Inspirasi memiliki pengaruh yang positif terhadap pertumbuhan gereja GBI House of Glory Batam. Oleh karena itu peneliti dalam hal ini mempunyai pertimbangan dari hasil yang sudah didapatkan maka peneliti menyampaikan:

1. Kerinduan akan Allah adalah adalah kunci kualitas kerohanian yang baik! Orang-orang Kristen perlu memahami sikap kerinduan akan Allah banyak digambarkan dalam pengalaman Daud di dalam mazmur.

2. Penatalayanan gereja (jemaat) yang baik, tertib dan teratur harus menyangkut aspek: perencanaan, pengorganisasian, pelaksanaan, pengawasan, pelaporan dan pertanggung jawaban pelayanan. Seluruh penatalayanan dalam gereja mengenai sumber dayanya harus berkontribusi pada peneguhan dan penyatuan gereja, sebagai persiapan bagi pelayanan dan misi dunia.

3. Ibadah yang dipersiapkan dengan baik akan membangkitkan inspirasi bagi setiap orang yang datang beribadah. Ibadah yang membangkitkan inspirasi adalah ibadah yang di dalamnya ada hati yang mengasihi Kristus dan yang mengasihi orang-orang, jemaat yang menyanyi dengan sepenuh hati, keterbukaan terhadap pimpinan Roh Kudus, dan kerinduan untuk bersekutu dengan Allah Bapa 


\section{KEPUSTAKAAN}

Cunningham, Richard B. Creative Stewardship. Nashville: Abingdon Press, 1979.

D.M.Lintong. Tugas Pelayanan Pendeta. Tomohon: Lembaga Telaah Agama dan Kebudayaan(LETAK), 2005.

Endra, Himawan Djaya. Dewasa Dalam Kristus. Jakarta: CV Bina Media Informasi, 2003.

Laia, Kejar Hidup. "Pertumbuhan Gereja Dan Penginjilan Di Kepulauan Nias." Jurnal Fidei 2, no. 2 (2019): 286-302.

Robinson, Darrel W. Total Church Life. Bandung: Lembaga Literatur Baptis, 1985.

Saputro, Dwidjo. "Injil Dalam Ruang Kekuatan Keluarga Dan Pernikahan." Webinar Great Commission As Family Lasting Legacy, STT REAL BATAM.

Schwarz, Christian A. Pertumbuhan Gereja Yang Alamiah, Terj. Budijanto. Jakarta: Metanoia, 1996.

Tomatala, Yakob. Teologi Misi. Jakarta: YT Leadership Foundation, 2003.

Towns, Elmer. Effective Evangelism View: Church Growth Effectively Confronts and Penetrate Culture," Dalam Evaluating Church Growth Movement: 5 Views, Ed. Gary McIntosh. Grand Rapids: Zondervan, 2004.

Wongso, Peter. Tugas Gereja Dan Misi Masa Kini. Surabaya: Yakin, 1981. 